07

\title{
Плазмохимическое травление в постростовой технологии фотоэлектрических преобразователей
}

\author{
() А.В. Малевская, Ю.М. Задиранов, Н.Д. Ильинская, Д.А. Малевский, П.В. Покровский \\ Физико-технический институт им. А.Ф. Иофрфе РАН, \\ 194021 Санкт-Петербург, Россия \\ e-mail: amalevskaya@mail.ioffe.ru
}

Поступило в Редакцию 28 октября 2021 г.

В окончательной редакции 25 января 2022 г.

Принято к публикации 25 января 2022 г.

\begin{abstract}
Проведены исследования плазмохимической технологии травления гетероструктур при формировании каскадных фотоэлектрических преобразователей. Рассмотрен этап формирования разделительной мезаструктуры при различных режимах травления и последующего удаления нарушенного слоя методом жидкостной химической обработки гетероструктуры. Проведено исследование влияния методов травления мезы на электрические характеристики элементов. Разработана технология формирования фотоэлектрических преобразователей $\mathrm{c}$ низкими значениями токов утечки менее $10^{-9} \mathrm{~A}$ при напряжении менее $1 \mathrm{~V}$ с высокой стойкостью элементов к деградации.
\end{abstract}

Ключевые слова: фотоэлектрический преобразователь, гетероструктура, плазмохимическое травление, мезаструктура.

DOI: 10.21883/JTF.2022.04.52248.282-21

\section{Введение}

Концентраторные каскадные фотоэлектрические преобразователи (ФЭП) имеют наивысшую эффективность преобразования солнечного излучения [1-4]. Рекордные значения КПД для 6-каскадных ФЭП составляют 47\% при кратности концентрирования солнечного излучения 140x (AM 1.5) [2].

Наиболее распространенными являются трехкаскадные ФЭП на основе гетероструктуры $\mathrm{GaInP} / \mathrm{Ga}(\mathrm{In}) \mathrm{As} / \mathrm{Ge}$, включающей в состав более 20 разных по физическим и химическим свойствам слоев [3-6]. Проведение постростовой обработки данных гетероструктур при изготовлении ФЭП является весьма трудозатратной задачей. Исследования и разработки в области постростовой технологии изготовления ФЭП позволяют снизить омические и оптические потери путем оптимизации режимов формирования омических контактов и антиотражающих покрытий, а также снизить токи утечек при создании разделительной мезаструктуры [7].

В настоящей работе проведены исследования формирования разделительной мезы при изготовлении ФЭП на основе гетероструктуры $\mathrm{GaInP} / \mathrm{Ga}(\mathrm{In}) \mathrm{As} / \mathrm{Ge}$ методом плазмохимического травления на установке STE ICP 200e (SemiTEq). Оптимизированы режимы проведения процесса травления и обработки гетероструктур. Проведены оценки влияния параметров процесса на электрические характеристики ФЭП.

\section{1. Параметры плазмохимического травления}

Одним из этапов постростовой обработки гетероструктур при изготовлении ФЭП является разделение пластины на чипы. Для снижения токов утечки по периметру чипа предлагается проводить травление слоев гетероструктуры $\mathrm{GaInP} / \mathrm{Ga}(\mathrm{In}) \mathrm{As}$ и германиевой подложки на глубину $10-15 \mu \mathrm{m}$, в 2 раза превышающую толщину слоев гетероструктуры, для защиты торца $p-n$-переходов от механического воздействия при резке гетероструктур. Широко используемым методом формирования мезаструктуры является плазмохимическое травление в комбинированной плазме индуктивного и емкостного разряда (ICP/RIE) в потоке рабочего газа $\mathrm{BCl}_{3}[8,9]$.

Процесс плазмохимического травления включает набор технологических параметров, оказывающих влияние на скорость травления отдельных слоев гетероструктуры, на стойкость маски фоторезиста, используемой для защиты фоточувствительной области элементов, и на качество поверхности мезаструктуры в целом. Для оптимизации режимов выполнен ряд исследований при варьировании различных технологических параметров плазмохимического травления.

Основными параметрами процесса являются: давление $(P)$ в камере, мощность индуктивно связанной плазмы (ICP), мощность смещения (RIE), напряжение смещения $(U)$, температура столика $(T)$, на котором располагается гетероструктура. Изменение этих параметров оказывает влияние на скорость травления 


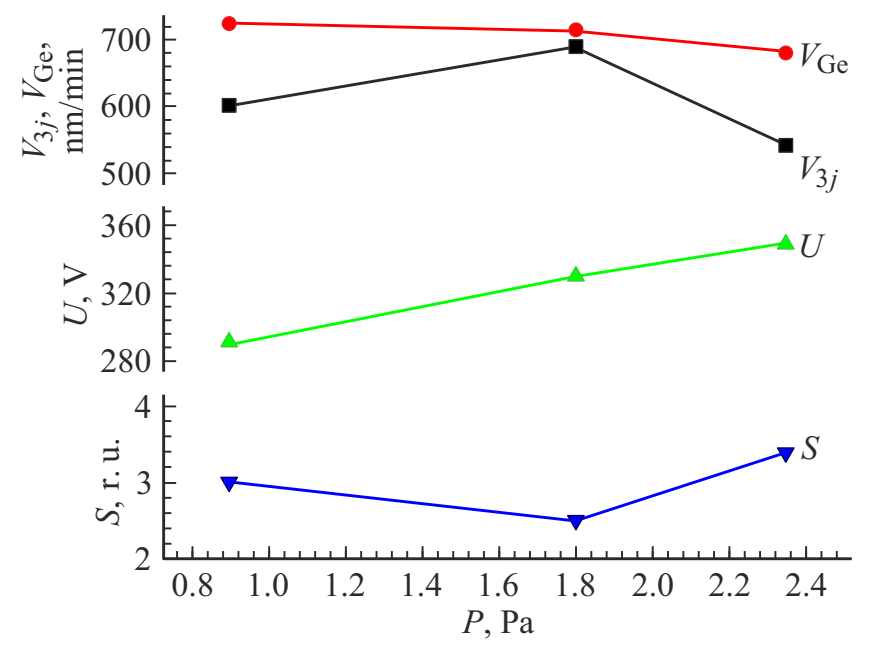

Рис. 1. Зависимость скорости травления структуры $\left(V_{3 j}, V_{\mathrm{Ge}}\right)$, напряжения смещения $(U)$ и селективности $(S)$ от давления в камере.

слоев гетероструктуры $\mathrm{GaInP/Ga}(\mathrm{In}) \mathrm{As}\left(V_{3 j}\right)$, скорость травления германиевой подложки $\left(V_{\mathrm{Ge}}\right)$, селективность травления структуры по отношению к защитной маске $(S)$. Параметр селективности травления определяет различие скоростей травления слоев структуры и маски, и соответственно характеризует степень защиты структуры в процессе формирования мезы.

Для оценки влияния большого набора параметров на протекание технологического процесса было проведено несколько независимых экспериментов при фиксированном значении ряда параметров и варьировании одного параметра попеременно. Для оценки влияния давления в камере на процесс травления заданы фиксированные значения: $\mathrm{ICP}=600 \mathrm{~W}, \mathrm{RIE}=100 \mathrm{~W}$ (рис. 1). Величина напряжения смещения электрода подложкодержателя является характеристикой процесса плазмохимического травления и определяет энергию и поток ионов на поверхность гетероструктуры. Температура столика задается постоянной $\sim 10^{\circ} \mathrm{C}$, что обеспечивает охлаждение обрабатываемой гетероструктуры и увеличивает стойкость маски фоторезиста.

Эксперимент показал, что при давлении в камеpe $\sim 1.8$ Ра наблюдается выравнивание скоростей травления слоев гетероструктуры и германиевой подложки, что позволяет формировать ровную боковую поверхность мезы. Селективность травления структуры по отношению к защитной маске варьируется от 2.5 до 3.5 , что обеспечивает стойкость маски, достаточную для формирования разделительной мезы глубиной $10-15 \mu \mathrm{m}$.

Для оценки влияния мощности индуктивно связанной плазмы (ICP) на процесс травления заданы фиксированные значения: $\mathrm{RIE}=100 \mathrm{~W}, P=1.8 \mathrm{~Pa}$ (рис. 2). Выравнивание скоростей травления наблюдается при $\mathrm{ICP}=600 \mathrm{~W}$.
Для оценки влияния мощности смещения (RIE) на процесс травления заданы фиксированные значения: $\mathrm{ICP}=800 \mathrm{~W}, P=1.8 \mathrm{~Pa}$ (рис. 3). Выравнивание скоростей травления наблюдается при RIE $=100 \mathrm{~W}$.

В результате проведенного исследования были определены оптимальные параметры плазмохимического травления гетероструктуры $\mathrm{GaInP} / \mathrm{Ga}(\mathrm{In}) \mathrm{As} / \mathrm{Ge}$ в потоке рабочего газа $\mathrm{BCl}_{3}$ : мощность индуктивно связанной плазмы $\mathrm{ICP}=600 \mathrm{~W}$, мощность смещения $\mathrm{RIE}=100 \mathrm{~W}$, напряжение смещения $U=290 \mathrm{~V}$, давление в камере $P=1.8 \mathrm{~Pa}$, температура столика $T=10^{\circ} \mathrm{C}$. Данные параметры процесса обеспечивают формирование разделительной мезаструктуры с ровной боковой поверхностью за счет выравнивания скоростей травления разных по физико-химическим свойствам слоев гетероструктуры $\mathrm{GaInP} / \mathrm{Ga}(\mathrm{In}) \mathrm{As}$ и германиевой подложки. При этом формируется поверхность травления высокого качества,

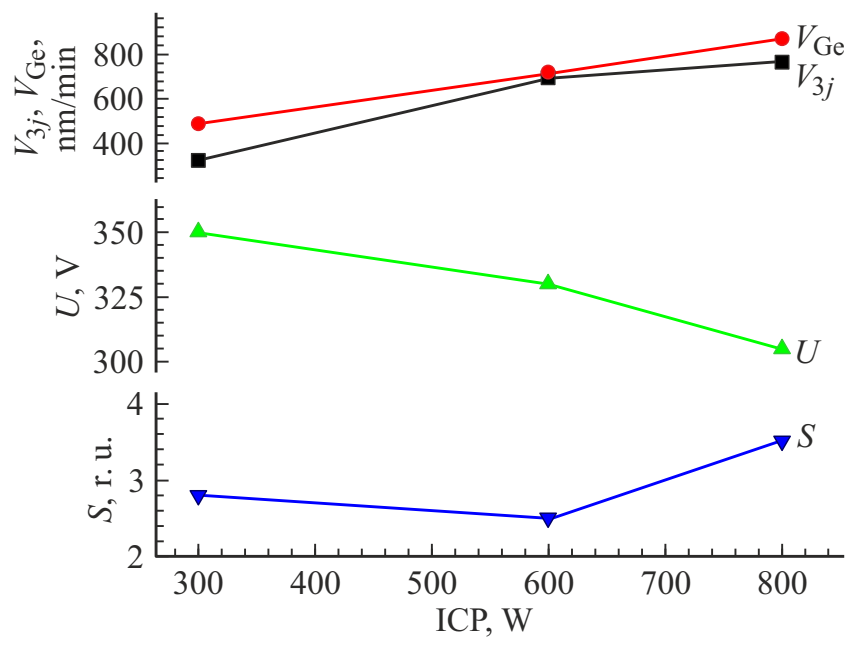

Рис. 2. Зависимость скорости травления структуры $\left(V_{3 j}, V_{\mathrm{Ge}}\right)$, напряжения смещения $(U)$ и селективности $(S)$ от мощности индуктивно связанной плазмы (ICP).

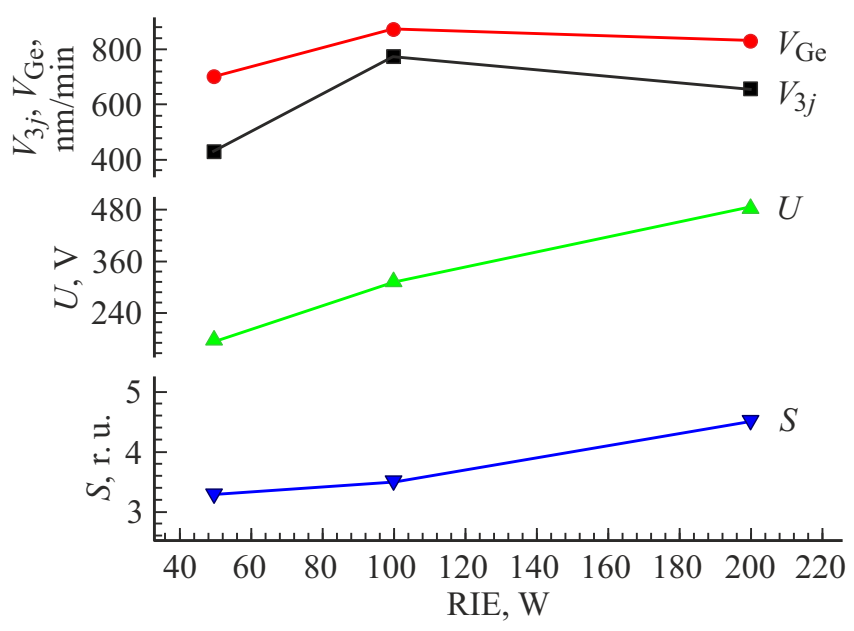

Рис. 3. Зависимость скорости травления структуры $\left(V_{3 j}, V_{\mathrm{Ge}}\right)$, напряжения смещения $(U)$ и селективности $(S)$ от мощности смещения (RIE). 

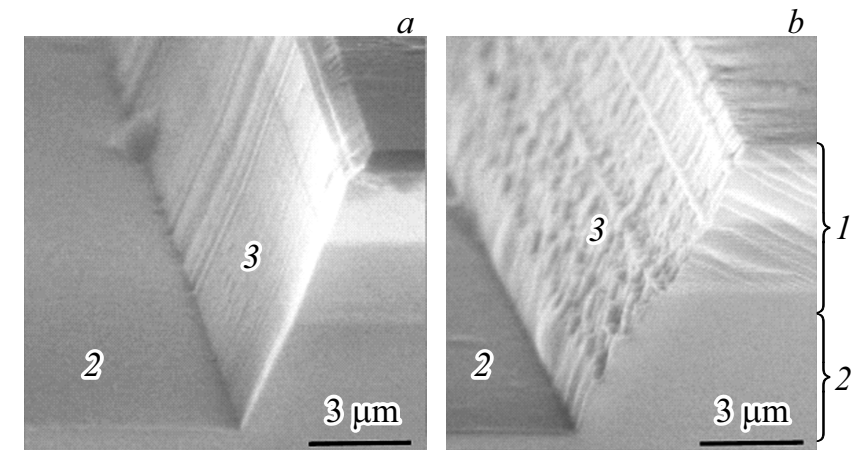

Рис. 4. Фотография скола мезаструктуры, выполненная на растровом электронном микроскопе, после плазмохимического травления $(a)$, после удаления нарушенного слоя при травлении в $\mathrm{H}_{2} \mathrm{SO}_{4}: \mathrm{H}_{2} \mathrm{O}_{2}: \mathrm{H}_{2} \mathrm{O}$ на $100 \mathrm{~nm}(b) .1$ - гетероструктура $\mathrm{GaInP} / \mathrm{Ga}(\mathrm{In}) \mathrm{As}, 2$ - германиевая подложка, 3 - боковая поверхность мезаструктуры.

без дефектов, что обеспечивает снижение токов утечки по боковой поверхности мезы в местах выхода $p-n$ переходов (рис. 4, $a$ ). Селективность травления слоев структуры и защитной маски фоторезиста $(S>2.5)$ обеспечивает надежную защиту фоточувствительной области ФЭП и снижает вероятность возникновения дефектов и протравов структуры.

\section{2. Удаление нарушенного слоя}

При плазмохимическом травлении слоев гетероструктуры образуется нарушенный слой, который может привести к деградации элементов при работе в агрессивных условиях окружающей среды, а именно при перепадах температур и высокой влажности. Для удаления нарушенного слоя в настоящей работе осуществлялась обработка поверхности мезаструктуры методом жидкостного химического травления на глубину 30-100 nm.

Проведено исследование способов травления мезы с использованием ряда сильноразбавленных травителей на основе ортофосфорной или серной кислоты с добавлением перекиси водорода. В результате обработки в жидкостных химических травителях наблюдается ухудшение морфологии боковой поверхности мезы, что связано с различием скоростей травления разных по химическим свойствам слоев гетероструктуры (рис. 4, $b$ ), однако искажение профиля незначительно, протравов по отдельным слоям гетероструктуры не наблюдается, а проведение анализа влияния методов обработки поверхности на электрические характеристики ФЭП показало снижение токов утечки на темновых вольт-амперных характеристиках (рис. 5). Результаты исследования показали, что удаление нарушенного слоя в жидкостных травителях на основе ортофосфорной или серной кислот с добавлением перекиси водорода при травлении на глубину $\sim 30 \mathrm{~nm}$ привело к небольшому снижению токов утечки. Наилучший результат достигнут при обработке

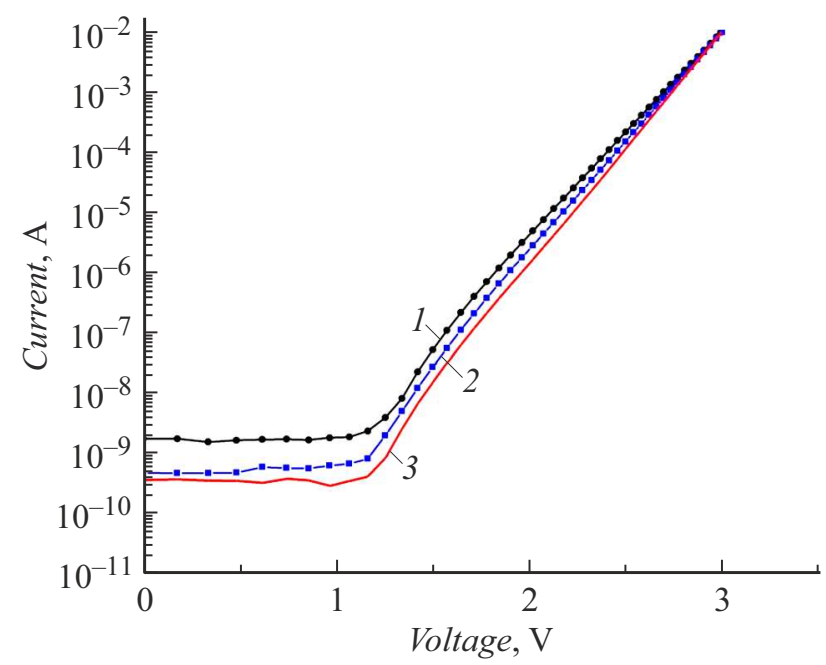

Рис. 5. Темновые вольт-амперные характеристики ФЭП после создания разделительной мезаструктуры методами плазмохимического травления: 1 - без обработки, 2 - травление в $\mathrm{H}_{2} \mathrm{SO}_{4}: \mathrm{H}_{2} \mathrm{O}_{2}: \mathrm{H}_{2} \mathrm{O}$ на $30 \mathrm{~nm}, 3$ - травление в $\mathrm{H}_{2} \mathrm{SO}_{4}: \mathrm{H}_{2} \mathrm{O}_{2}: \mathrm{H}_{2} \mathrm{O}$ на $100 \mathrm{~nm}$.

в травителе на основе серной кислоты и перекиси водорода при травлении на глубину $\sim 100 \mathrm{~nm}$, токи утечки составили менее $10^{-9}$ А при напряжении менее $1 \mathrm{~V}$.

\section{3. Уменьшение деградации ФЭП при термоциклировании}

Для анализа качества поверхности мезы и стойкости готовых ФЭП к деградации проведено термоциклирование элементов с разными вариантами обработки поверхности. Количество исследуемых ФЭП составило порядка 100 элементов. Было выполнено 10 циклов, состоящих из нагрева ФЭП до $+85^{\circ} \mathrm{C}$, выдержки их при заданной температуре и $85 \%$ влажности в течение 20 h и охлаждения до $-40^{\circ} \mathrm{C}$. Этот тип испытаний определяет способность ФЭП противостоять воздействию высокой температуры и высокой влажности с последующим охлаждением до температуры ниже температуры замерзания.

Результаты исследования показали, что при формировании мезаструктуры методом плазмохимического травления без проведения дополнительной обработки поверхности и удаления нарушенного слоя деградируют $\sim 20 \%$ ФЭП после проведения термоциклирования. Удаление нарушенного слоя в сильноразбавленных травителях на основе ортофосфорной или серной кислоты с добавлением перекиси водорода при травлении на глубину $30 \mathrm{~nm}$ снизило процент деградированных ФЭП до $10-15 \%$, а при травлении на глубину $100 \mathrm{~nm}$ процент дергадированных ФЭП уменьшился до величины $\sim 6 \%$. Деградация ФЭП заключалась в проявлении каналов утечки на темновых вольт-амперных характеристиках, при этом происходило увеличение токов утечки до величин более $10^{-7}$ А при напряжении менее $1 \mathrm{~V}$. 


\section{Заключение}

В работе проведен анализ темновых вольт-амперных характеристик ФЭП, который показал, что состояние боковой поверхности разделительной мезы (в местах выхода $p-n$-переходов) после проведения плазмохимического травления и дополнительной обработки поверхности оказывает существенное влияние на электрические параметры ФЭП. Наличие нарушенного слоя, составляющего всего единицы-десятки нанометров на боковой поверхности мезы, в котором образуются каналы проводимости, ведет к увеличению паразитных токов утечки. А нарушение поверхностной кристаллической структуры приводит к снижению стойкости ФЭП к воздействию окружающей среды: к перепадам температуры и влажности, что приводит к ускоренной деградации ФЭП, заключающейся в проявлении каналов утечки, и соответственно в ухудшении фотоэлектрических характеристик, таких, как КПД и максимальная генерируемая мощность.

Выполнен анализ влияния параметров плазмохимического травления на ход протекания процесса. Важным аспектом является нелинейные зависимости скорости травления слоев гетероструктуры $\mathrm{GaInP} / \mathrm{Ga}(\mathrm{In}) \mathrm{As} / \mathrm{Ge}$ от давления в камере, мощности индуктивно связанной плазмы (ICP) и мощности смещения (RIE), что может быть обусловлено физическими особенностями протекания процесса, такими, как баланс скорости подвода реагентов в область травления и отвода продуктов реакции.

Проведена разработка и оптимизация параметров плазмохимического травления слоев трехкаскадной гетероструктуры GaInP/Ga(In)As/Ge ФЭП для формирования разделительной мезаструктуры. Проведены исследования методов удаления нарушенного слоя на боковой поверхности мезы, и достигнуто снижение количества деградирующих ФЭП в 3 раза (до величины 6\%) путем оптимизации процесса плазмохимического травления с последующей обработкой поверхности методом жидкостного химического травления. При этом величина токов утечки уменьшена до величины менее $10^{-9} \mathrm{~A}$ при напряжении менее $1 \mathrm{~V}$. Результаты исследования показали высокую стабильность и воспроизводимость параметров ФЭП, изготавливаемых с использованием разработанной постростовой технологии.

\section{Конфликт интересов}

Авторы заявляют, что у них нет конфликта интересов.

\section{Список литературы}

[1] Zh.I. Alferov, V.M. Andreev, V.D. Rumyantsev. „III-V Hetestructures in Photovoltaics“ in "Concentrator Photovoltaics“, ed. by A. Luque, V. Andreev. Springer Ser. in Optical Sciences (Springer, Berlin-Heidelberg, 2007), v. 130 , p. 25-50. DOI: 10.1007/978-3-540-68798-6_2
[2] M.A. Green, E.D. Dunlop, J. Hohl-Ebinger, M. Yoshita, N. Kopidakis, X. Hao. Solar Cell Efficiency Tables (Version 58). Prog. Photovolt.: Res. Appl., 29 (1), 657 (2021). DOI: $10.1002 /$ pip.3444

[3] Zh.I. Alferov, V.M. Andreev, M.Z. Shvarts. JII-V Solar Cells and Concentrator Arrays" in High Efficient LowCos Photovoltaics“, ed. by V. Petrova-Koch, R. Hezel, A. Goetzberger (Springer Ser. in Optical Sciences, 2020), v. 140 , p. $133-174$. DOI: 10.1007/978-3-030-22864-4_8

[4] Handbook of Concentrator Photovoltaic Technology, ed. by Carlos Algora, Rey-Stole Ignacio (John Willey\&Sons, Ltd, 2016)

[5] Е.В. Слыщенко, А.А. Наумова, А.А. Лебедев, М.А. Генали, Н.Т. Вагапова, Б.В. Жалнин. Сибирский журнал науки и техники, 19 (2), 308 (2018).

[6] M.E. Levinshtein, Semiconductor Technology (WileyInterscience Publication, USA, 1997)

[7] А.В. Малевская, Д.А. Малевский, П.В. Покровский, В.М. Андреев. Письма в ЖТФ, 46 (19), 35 (2020). DOI: 10.21883/PJTF.2020.19.50043.18375

[8] M. de Lafontaine, E. Pargon, C. Petit-Etienne, G. Gay, A. Jaouad, M.-J. Gour, M. Volatier, S. Fafard, V. Aimez, M. Darnon. Solar Energy Materials and Solar Cells, 195, 49 (2019). DOI: 10.1016/j.solmat.2019.01.048

[9] А.В. Малевская, Ю.М. Задиранов, Д.А. Малевский, П.В. Покровский, Н.Д. Ильинская, В.М. Андреев. Письма в ЖТФ, 47 (3), 14 (2021). DOI: 10.21883/PJTF.2021.03.50568.18446 